First Peoples Child \& Family Review

An Interdisciplinary Journal Honouring the Voices, Perspectives, and Knowledges of First Peoples through Research, Critical Analyses, Stories, Standpoints and Media Reviews

\title{
Aboriginal Youth Gangs in Canada: (de)constructing an epidemic
}

\section{Raven Sinclair and Jana Grekul}

Volume 7, Number 1, 2012

URI: https://id.erudit.org/iderudit/1068862ar

DOI: https://doi.org/10.7202/1068862ar

See table of contents

Publisher(s)

First Nations Child and Family Caring Society of Canada

ISSN

1708-489X (print)

2293-6610 (digital)

Explore this journal

Cite this article

Sinclair, R. \& Grekul, J. (2012). Aboriginal Youth Gangs in Canada:

(de)constructing an epidemic. First Peoples Child \& Family Review, 7(1), 8-28.

https://doi.org/10.7202/1068862ar

\section{Article abstract}

The literature on gang activity in Canada indicates a proliferation of Aboriginal youth gangs, and the research tells us that child welfare involvement is a significant risk factor for gang participation. This article examines the child welfare and youth gang literature, and analyzes the complex interaction of structural factors facing Aboriginal youth in Canada in order to contextualize youth gang involvement within the larger system of social distress facing Aboriginal people. This paper scrutinizes the veracity of youth gang statistics and interrogates the Aboriginal youth gang discourse to discover that, although a problem clearly exists, the scope and substance of the situation in Canada needs to be more thoroughly researched in order to be accurately portrayed.
This document is protected by copyright law. Use of the services of Érudit (including reproduction) is subject to its terms and conditions, which can be viewed online.

https://apropos.erudit.org/en/users/policy-on-use/ 


\title{
First Peoples Child \& Family Review
}

An Interdisciplinary Journal Honoring the Voices, Perspectives and Knowledges of First Peoples through Research, Critical Analyses, Stories, Standpoints and Media Reviews

\section{Volume 7, Number 1, 2012, pp. 8-28}

\section{Aboriginal Youth Gangs in Canada: (de)constructing an epidemic}

\author{
Raven Sinclaira, and Jana Grekul ${ }^{b}$ \\ ${ }^{a}$ Associate Professor, Faculty of Social Work, University of Regina, Saskatoon, SK, Canada \\ ${ }^{\mathrm{b}}$ Associate Professor, Faculty of Sociology, University of Alberta, Edmonton, AB, Canada
}

\begin{abstract}
The literature on gang activity in Canada indicates a proliferation of Aboriginal youth gangs, and the research tells us that child welfare involvement is a significant risk factor for gang participation. This article examines the child welfare and youth gang literature, and analyzes the complex interaction of structural factors facing Aboriginal youth in Canada in order to contextualize youth gang involvement within the larger system of social distress facing Aboriginal people. This paper scrutinizes the veracity of youth gang statistics and interrogates the Aboriginal youth gang discourse to discover that, although a problem clearly exists, the scope and substance of the situation in Canada needs to be more thoroughly researched in order to be accurately portrayed.
\end{abstract}

\section{Introduction}

This article arises out of a review requested by the Office of the Federal Interlocutor to examine risk factors related to Aboriginal children in alternative care and subsequent gang involvement. Literature addressing Aboriginal child welfare, criminalization, and gang statistics was explored to ascertain the scope of the problem, and to assess the links to child welfare involvement. In the course of the exploration, an overview of the issue of Aboriginal youth gangs in Canada emerged that leaves us with some insights into the issue, an awareness of where gaps in understanding exist, and ideas for further research.

The context of Aboriginal youth gangs was viewed through a critical structural and historical lens. The critical structural foundation of the analysis encompasses the principles of critical pedagogy and conscientization (Freire, 1972). Critical pedagogy is concerned with helping students develop a higher awareness of conditions of oppression and inequality in order to change the world (Leonard, 1990, cited in Mulally 1997, p. 108), while conscientization is defined as "critical consciousness" (Freire, 1972) about those systems, including the ability to critically analyze and respond. In examining Aboriginal youth issues, a critical perspective directs our attention to the emancipation of youth as an

Address correspondence to:

Raven Sinclair, 153-111 Research Drive,

Saskatoon, SK, S7N 3R2, (306) 644-7372;

Email: ravsin@sasktel.net oppressed group, through critique and then action. The critique deconstructs systems of domination and inequality, and action is invested in the transformation of those conditions of inequality (Mullaly, 1997; Kellner, 1989). 
First Peoples Child \& Family Review, Volume 7, Number 1, 2012

Acknowledgement: Financial support for the report on which this article is based was provided by the Office of the Federal Interlocutor.

Structuralism reminds us that conditions must be understood within larger, overarching systems, particularly because the systems may be underlying causes for social problems (Weinberg, 2008). Without a critical structural approach, there is a risk that Aboriginal youth will be blamed for their problems. We understand that Aboriginal youth gang involvement has clear antecedents that can be traced back to socio-economic and political inequities, appropriately referred to as a "burden of suffering" (Totten, 2009b) brought about through colonization; in particular, the programs of successive governments to assimilate Aboriginal people into the mainstream body politic (Sinclair, 2007a). The historical lens ensures that we are not "operating in a vacuum" with respect to Aboriginal issues (Duran \& Duran, 1995), and a historical analysis situates Aboriginal youth and gang issues within the macro socio-political and economic context that frames contemporary Aboriginal issues. In the words of the Elders, "we have to know where we have been to know where we are going" (Sinclair, 2009, p.19).

At first glance, the literature clearly establishes disruption during developmental or adolescent stages, through parental or guardian neglect or abuse, as a risk factor for gang involvement (Goodwill 2009). The Aboriginal child welfare system, which is a direct consequence of the destruction of families through the Residential School system, also presents a key risk factor to increased Aboriginal youth mental concerns, homelessness, attachment disorders, and juvenile criminality (Dukes et al., 1997; Neckoway et al., 2003; Gilchrist, 1995; Trevethan et al., 2002), as well as low educational attainment, poverty, and suicide (Totten, 2008). All these factors subsequently make Aboriginal youth vulnerable to youth gang recruitment and put them at risk of incarceration, which has been described as a "training ground" for gangs (Mercredi, 2000). These youth issues are further nested within the context of Aboriginal marginalization and oppression, racism, cultural disruption, and the loss of traditional culture and knowledge translation, family and community disruption, as well as poverty, mental health, burgeoning and chronic disease (Adelson, 2005 ; Bennett et al., 2005; Grekul \& LaBoucane-Benson, 2007; Sinclair, 2007a; Reading, 2010).

Bennett et al. (2005) remind us that

socio-economic problems today are so pervasive for First Nations peoples that a 1996 internal Department of Indian and Northern Affairs study found that if the United Nations Human Development Index were applied to First Nations living on reserve they would rank 79th and 80 th in the world while at the same time, Canadians as a whole, are ranked number one in the world. (p. 7)

These realities help one to understand the etiology of and structural connections to Aboriginal youth gang involvement. Goodwill (2009) observes that Aboriginal gangs in Canada "could not be discussed without the context of the literature documenting the history and effects of colonialism, as well as Aboriginal culture, resilience and healing" (p. 30). Aboriginal youth gang involvement is inextricably linked to the social distress caused by colonization. Ironically, a current reality is that most Aboriginal people, gang-involved or not, experience many of the same socio-economic antecedents to gang involvement that youth gang members do.

The connection between the aggressions of recent colonial history to contemporary youth issues, as well as family violence and other social pathologies, can be traced through as many 


\section{Aboriginal youth gangs in Canada: (de)constructing an epidemic}

as five generations of family members, reaching back to the early 1800s. Armitage (1995, cited in Bennett et al., 2005) observed that residential schools were effective preparation sites for the institutionalization of prisons and mental health facilities since so many former students ended up there. Since residential schools began closing with increasing frequency into the 1980s, some Aboriginal families now have up to three generations who did not attend the schools. However, most of the current generations have been significantly affected by the child welfare system that emerged in the early 1960s (Sinclair, 2007a).

\section{The Aboriginal Child Welfare System}

The child welfare system in Canada developed rapidly as the result of two key events: the gradual closing of residential schools, and the 1951 amendment to the Indian Act that allowed provinces to deal with Aboriginal child welfare issues (Bennett et al., 2005, p. 19). Among the dynamics occurring at the time were the new provincial jurisdictions, a relatively new social work profession, a clash between mainstream and Aboriginal cultures, social problems and disarray stemming from residential schools, and intense poverty and disenfranchisement on reserves (Bennett et al., 2005; Sinclair, 2007a). The introduction of federal transfers through the Canada Assistance Plan in 1966 allowed provinces to invest more energy into child welfare matters, leading to exponential growth in the Aboriginal child welfare arena (Sinclair, 2007b). This translated into high numbers of relinquished and apprehended Aboriginal children and their subsequent placement in foster and adoptive homes. This period, referred to as the "Sixties Scoop," saw over 11,000 status Aboriginal children adopted into non-Aboriginal homes in Canada and around the world (Timpson, 1995; Johnston, 1983).

By the 1970s, one in three Aboriginal children were separated from their families by adoption or fostering (Fournier \& Crey, 1997). That decade was marked by a significant increase in Aboriginal children in care in Canada - 44 per cent in Alberta, 51 per cent in Saskatchewan, and 60 per cent in Manitoba (McKenzie \& Hudson, 1985, p. 126). Currently, child-in-care statistics are even more problematic; an estimated 80 per cent of the children and youth in out-of-home care in the province of Saskatchewan at the end of the 2008/09 fiscal year were Aboriginal (Sask., 2010). The statistics are comparable to both British Columbia and Manitoba, both of which have high Aboriginal populations, and both of which were the most intensely affected by the child welfare system (Sinclair, 2007b). Gough et al. (2005) observed that assimilation policies led to higher incidents of child removal and the overrepresentation of Aboriginal children in care, because Aboriginal children were relinquished and apprehended at twice the rate of non-Aboriginal children, primarily owing to socioeconomic conditions, alcohol abuse, neglect, criminal activity, and cognitive impairment (p. 2).

\section{Non-Aboriginal Alternative Care}

The alternative care system has harmful effects on children generally (Brand \& Brinich, 1999) and the current system is primarily populated with Aboriginal youth and children. Despite attempts to recruit Aboriginal foster and adoptive homes, the literature indicates that most Aboriginal children in alternative care are placed in non-Aboriginal homes (Maurice, 2003; Bennet et al., 2005; Sinclair, 2007a). The placement of Aboriginal children into non-Aboriginal contexts is problematic on many fronts: children's bonds and attachment to families and communities is disrupted, children are separated from exposure to language and culture, children are socialized 
in non-Aboriginal contexts with concomitant cultural expectations, and children are vulnerable as members of a marginalized and oppressed minority group.

In alternative care contexts, particularly in a racialized milieu, Aboriginal children are extremely vulnerable. In racialized contexts, vulnerability carries with it an added danger of discriminationbased harm, which has been confirmed by narratives of adults who were involved in the child welfare system (Sinclair, 2007a; Stolen Generations, 2003). Children in the child welfare system are in a state of complete vulnerability because of their dependence on assigned caregivers for their wellbeing and survival. They are defenceless and unprotected, first, because their primary parental and family bonds have been damaged, and second, because they are at the mercy of the good will of their substitute family. Bennett et al (2005 citing Proulx and Perrault, 1996) found that children who were removed from their parents were less likely to form strong attachments with others, resulting in less social control and an increased likelihood they will break the law. Multiple placements have the overall effect of reducing opportunities to bond with others, a finding that is increasingly supported by research conducted on inmates in prison (Trevethan et al., 2002; RCAP, 1996; Waldram, 1997).

The level of life risk for Aboriginal children in care is high, and the numbers of children who have died in care indicates that they are extremely vulnerable to harm (Cradock, 2007). In Saskatchewan alone there were 64 deaths of children in care in 2000 and 2001. Fifty-six of those children were Aboriginal (First Nation, Métis, Non-status, and Aboriginal status unknown) (SCA 2005). The Canadian Incidence Study of Reported Child Abuse and Neglect (2001) confirms that being a child-in-care is a significant risk factor for harm:

What is known is that all Canadian children who receive child protection services have been deemed at significant risk of, or are actual victims of child abuse, neglect and maltreatment. (Trocme et al., 2001)

\section{Aboriginal Child Welfare as a Pathway to Gang Involvement}

Aboriginal child welfare as a factor implicated in gang involvement and criminality is quite firmly established in the literature. A study conducted in 2001 noted that 60 per cent of Aboriginal inmates in federal penitentiaries are products of the foster care or adoption system in Canada (Trevethan et al., 2002). Similarly, 60 per cent of homeless Aboriginal youth in three of Canada's largest cities (Vancouver, Toronto, and Montreal) who participated in a research study in 1995 came out of the foster care and adoption systems (Gilchrist, 1995), and Toronto Native Child and Family Services reported regular requests for help from homeless, former foster/adoptee youth, particularly in the two decades preceding the report (Stevenato, 1999).

Looking deeper, the path from child welfare to gang involvement is exacerbated through the dislocation of Aboriginal children that manifests in trust and attachment problems, as well as an array of mental health issues. Attachment disordered children suffer a range of behavioural, emotional, and mental health problems connected to earlier upsets and losses, and these effects can carry into adulthood, affecting behaviour and interpersonal relationships over a lifetime (Bowlby ,1973; Brandon et al., 1999). Golding (2003) found that attachment is shown to be a predictor of social, cognitive, behavioural, and academic performance, and in an Aboriginal context, these attachment issues may be even more complex than standard attachment theory implies. Conventional attachment theory is grounded in a nuclear family context (Neckoway et al., 2007), and can be criticized for overlooking cultural socio-political aspects of Aboriginal 


\section{Aboriginal youth gangs in Canada: (de)constructing an epidemic}

family and community systems that may be important in the lives of Aboriginal children whose families of origin, since time immemorial, include much larger networks of relatives than EuroCanadian families.

Vulnerability, abuse and harm, and attachment problems in youth create susceptibility to juvenile delinquency, disenfranchisement, and gang recruitment. Gang members themselves state that their peers who have been raised in care make good targets for recruitment because gangs promise to act as family substitutes (Grekul \& LaBoucane-Benson, 2008). In the words of a former gang member,

The kinds of kids that are attractive to gangs are street kids without close family. These kids want love and respect and the gang provided that for them. Kids within the family services system are really attractive to gangs. (p. 68)

\section{Interrelated Factors that contribute to Gang Involvement}

Vulnerability to gang involvement occurs in a several more interrelated ways. Intergenerational dysfunction in families of origin may lead to gang involvement, and where family members are gang-involved they may also be a source of recruitment (Grekul \& LaBoucane-Benson, 2008). Thirty per cent of gang members in one study reported unsafe and unsupportive parenting practices that included families of origin as well as foster homes. One participant stated: "I learned violence from foster homes, those disciplinarians ... that's how I learned to be adapted to anybody" (Goodwill 2009). In some instances the search for identity, peer support, and belonging are sparked by out-of home care and/or family dysfunctions (Grekul \& LaBoucaneBenson, 2008).

Mental health problems may also lead to gang involvement because the mental wellbeing of families is either an insulating or a risk factor for youth issues later on (McCormick, 1994; Chandler \& Lalonde, 1998). A 1995 study by two Aboriginal psychologists in Oakland, California found that 75 per cent of Aboriginal people attending their clinic, even if their presenting symptoms were not described in terms of Post Traumatic Stress Disorder (PTSD), were suffering effects that met the clinical diagnosis for PTSD (Duran \& Duran, 1995). Similarly, Kirmeyer, Tait, and Brass (2000) articulate the connections between colonization, colonialism, and the current rates of mental health problems among Aboriginal people. Among youth, distress is readily assessed through suicide rates, which are between five per cent and 20 per cent higher than in non-Aboriginal youth, although Aboriginal communities vary greatly in their suicide rates (Chandler \& Lalonde, 1998). Interrelated factors such as educational and employment inequities and marginalization of aboriginal youth (Grekul \& Laboucane-Benson, 2007a) contribute to high frustration levels; a perception of lower socio-economic potentiality, as well as reduced selfesteem and assorted psychological and emotional comorbidities.

Many young people feel they will never succeed in school or get a good job and they quite often experience boredom and a feeling of not being able to face the future. (Bennett et al., p. 43 citing Minore, Boone, Katt \& Kinch, 1991).

The interrelated factors span micro (individual), mezzo (community), and macro (policy/ society) levels and support the hypothesis that family and community social and emotional bonds and attachment, which ordinarily play a significant role in socialization and social control, are more tenuous in the fragility of the Aboriginal post-Residential School context (Grekul \& Laboucan-Benson, 2007, p. 30). In sum, the factors that are implicated in gang involvement 
become clearer when viewed through a critical structural and structural lens. Evidence of the scope of the Aboriginal youth gang problem, however, is not readily available, and so the attention in this article now turns to critiquing the existing data and deconstructing the prevailing discourse about Aboriginal youth gangs in order to arrive at a better understanding of the scope and substance of the issue.

\section{The Scope of the Gang Problem}

The academic literature on gang issues in Canada is sparse, and the literature on Aboriginal youth gangs is even more limited. There are a number of federally funded projects and a smattering of academic articles, as well as several Master's and $\mathrm{PhD}$ theses on gangs or gang-related topics. Hence, the collection of gang literature is small, relatively homogenous, limited in scope, and, in regard to statistics and themes, occasionally redundant. In other words, much of the information related to Aboriginal youth gangs in Canada can be gleaned from any one or two reports of the past decade. Grekul and LaBoucane-Benson (2008) note that the lack of research on Aboriginal youth gangs is a "glaring omission" in the gang literature (p. 61).

The most significant weakness in the literature is the problematic statistics upon which the Aboriginal gang "crisis" in Canada is premised. Here we see a phenomenon where reports, whether accurate or not, are reified over time through repetitive citing by subsequent authors who, for reasons unknown, neither critique nor confirm the veracity of the source material. No less than eight of the most prominent reports on Aboriginal gangs in the past decade cite one single source for Aboriginal gang statistics: a report titled, Results of the 2002 Canadian Police Survey (CPS) of Youth Gangs by Astwood Strategy Corporation.

Astwood Corporation was contracted to survey police jurisdictions and gather data on Aboriginal youth gang activities in as many regional jurisdictions as possible. The report is comprehensive, with solid methods, a sound sample size, and excellent response rates from police jurisdictions; however, what is problematic, and acknowledged as a limitation in the report, is that the numbers of gang members are based on stratified estimates. Only some of the jurisdictions reported estimates for gang numbers and member numbers, so for those that did not, the author stratified the data into "appropriate populations groups, and an average number of gangs and gang members were calculated for each group" (2002, 7).1 Although this is an appropriate approach, statistically speaking, population numbers are not included, so the accuracy of the estimates cannot be critiqued or verified. Given Canada's diverse population distributions, especially in relation to its geography, the data is important to assess accurately. For example, we cannot assume that a stratified ratio applied to a large urban centre such as Toronto could be appropriately applied to northern Ontario or the western provinces.

In sum, the Canadian Police Survey is based on qualitative information and must be used with caution because it is essentially an exploration of police perceptions of gang activity, with contrived numbers based on a perceived problem. In the intervening years since its publication, however, constant referencing of those hypothetical numbers by subsequent Canadian reports on Aboriginal Youth Gangs have effectively reified the statistics - that is, many authors have quoted the statistics as factual without assessing their qualitative limitations. A survey of reports citing the CPS 2002 stratified estimates include:

\footnotetext{
1 The CPS 2002 does not provide the stratified population data or population/gang ratio data.
} 


\section{Aboriginal youth gangs in Canada: (de)constructing an epidemic}

- Bania (2009). Gang violence among youth and young adults.

- Criminal Intelligence Service Saskatchewan (2005). Aboriginal-based gangs in Saskatchewan

- Preston, Carr-Stewart, and Northwest (2009). Aboriginal Youth Gangs: Preventative Approaches.

- Totten (2008, 2009a and 2009b). Totten (2009) cites Totten (2008), which references the CPS report.

- Chettleburgh (2007). Young Thugs.

- Criminal Intelligence Service Saskatchewan (2005).

- Public Safety Canada (2005, 2007, 2010).

- Mellor et al. (2005). Youth Gangs in Canada: A preliminary Review of programs and services.

- Public Safety and Emergency Preparedness Canada. Submitted by the Canadian Research Institute for Law and the Family. September (2005)

Examined in their totality, the statistics are problematic and occasionally contradictory. Synthesizing them does not provide an accurate picture of gang numbers generally, or Aboriginal numbers specifically. Table 1 below shows the numbers represented in the Canadian Police Survey and the Criminal Intelligence Service Canada (2006) report.

Table 1: Aboriginal Youth Gang Statistics

\begin{tabular}{|c|c|c|c|c|c|}
\hline Report & $\begin{array}{l}\text { \# of } \\
\text { Gangs }\end{array}$ & Total Members & Report & $\begin{array}{l}\text { \# of } \\
\text { Gangs }\end{array}$ & Total Members \\
\hline \multirow[t]{11}{*}{ CPS 2002} & 434 & 7071 & CISC 2006 & 300 & 11000 \\
\hline & None & $\begin{array}{l}\text { Yukon,NWT, Nunavut } \\
\text { PEI, Nfld/Labrador }\end{array}$ & & None & $\begin{array}{l}\text { Yukon, NWT, } \\
\text { Nunavut } \\
\text { PEI, Nfld/Labrador }\end{array}$ \\
\hline & 102 & $\mathrm{BC}-1027$ & & 20 & $\mathrm{BC}$ \\
\hline & 42 & Alberta - 668 & & 30 & Alberta \\
\hline & 28 & Saskatchewan - 1315 & & 21 & Saskatchewan \\
\hline & 15 & Manitoba - 171 & & 25 & Manitoba \\
\hline & 216 & 3320 & & 80 & Ontario \\
\hline & & & & $\star 95$ & $\begin{array}{l}\text { GTAincluding } \\
\text { Thunder Bay, Niagara } \\
\text { Falls, Ottawa }\end{array}$ \\
\hline & 25 & Quebec - 533 & & 50 & Quebec \\
\hline & 6 & Nova Scotia - 37 & & 10 & Nova Scotia \\
\hline & 0 & New Brunswick & & 7 & New Brunswick \\
\hline
\end{tabular}

CPS - Canadian Police Survey, Astwood Strategy Corporation, M. Chettleburgh

CISC - Criminal Intelligence Service of Canada 
A retrospective glance at a 1998 report by Soullière for the Canadian Police College - Report on Youth and Gangs - identified 335 youth gangs, 105 of which were involved in criminal activities between 1991 and 1992. Soullière admitted, however, that the numbers were unknown, and that estimates were made from consulting with police. Assuming that statistics as reported by police are accurate, and by comparing those numbers to the above, we would infer that in the four-year period between 2002 and 2006, the number of gangs in Canada dwindled by 33 per year while membership numbers increased by 1,000 each year. Such an increased concentration of members in fewer gangs would likely not go unnoticed or unreported, but that data is not reflected in other sources at this time.

Table 2: Comparison data

\begin{tabular}{|l|l|}
\hline Report & Numbers \\
\hline Metro Toronto Police - 1992 & 335 gangs (Toronto only) \\
\hline Canadian Police Survey - 2002 & 434 gangs, 7071 members \\
\hline $\begin{array}{c}\text { Criminal Intelligence Service Canada } \\
-2006\end{array}$ & $\begin{array}{c}300 \text { (175 in GTA, Thunder Bay, Niagara } \\
\text { and Ottawa), 11,000 members }\end{array}$ \\
\hline
\end{tabular}

It could be assumed that large increases or decreases in gang numbers would be noticed by police services as well as the general population, and reported in the media. However, subsequent Criminal Intelligence Service Canada (CISC) reports for the years 2007 to 2009, inclusive, omitted any reference to gangs. In 2010, the only CISC mention of gang activity was limited to the following comment regarding the size of the threat: "Since 2006 there has been an increase in the number of street gangs identified by law enforcement agencies across Canada" (18). An "increase" is not quantifiable and does not help provide statistical clarity.

In a 2007 publication Chettleburgh breaks down the statistics based on the data in the CPS 2002 survey. In the latter report he notes that Saskatchewan had 28 gangs and 1,315 members (14), while the book indicates that Saskatoon only had 11 gangs and 580 members, and Regina had 1 gang with 275 members. This could be a surprising but logical decrease inferred from the CPS if the data were based on actual numbers, but the more detailed statistics are still drawn from the same hypothetical estimates. Further, the latter statistics would surprise any Regina resident. Surely one gang with so many members would be noticeable to the public, given the familiar signs and symbols of gang affiliation in Saskatchewan, such as specifically coloured "rags" (bandanas) worn by members. How the Saskatchewan numbers were calculated is not provided. Even more interesting is the projection that Saskatoon is apparently a hotbed of gang activity with a per capita gang rate of 2.57 and Regina at 1.42 - the two highest rates in the country (p. 22).

In contrast to these numbers, the Criminal Intelligence Service of Saskatchewan in 2005 stated that all of Saskatchewan has 12 gangs (CISS 2005); a local gang exit project coordinator recently confirmed this statistic independently. At the street level in Saskatoon, Aboriginal consensus would most likely be that gangs are more of a problem in Manitoba, and in Winnipeg specifically. This is validated by Goodwill (2009) citing Sheremeta (1999), who noted that "Winnipeg Police department authorities reported 1400-1500 active gang members in the city, 75 per cent of whom were of Aboriginal descent" (p. 2). Those numbers are 700 per cent higher than Chettleburgh's 


\section{Aboriginal youth gangs in Canada: (de)constructing an epidemic}

estimates for Winnipeg (including all of Manitoba), and the gang numbers for Saskatchewan as indicated in the CISS are about 60 per cent fewer than Chettleburgh's estimate.

The notion that Saskatchewan is the epicenter for gang activity is not supported by other reporting. Constable C. Campbell-Waugh, in a 2008 panel discussion in the RCMP Gazette (2008), noted that the Canadian Centre for Justice Statistics had completed a study titled "Criminal Victimization in Canada."

The study revealed that among 17 Canadian cities surveyed, Halifax had the highest violent crime rate, with 229 violent incidents for every 1,000 people over age 15 . Youth gangs, with their involvement in violent street-level robberies, assaults, and weapons offences, were a major contributing factor.

Given the overall fragility of the existing statistics, the label of "epidemic" (Preston, 2009; Totten, 2009a; Totten, 2009b), often used to describe the gang situation, can justifiably be challenged, at least until more robust statistics can be gathered. Until such time as more accurate data collection strategies emerge, the scope of the Aboriginal Youth Gang problem must be reported with caution. Indeed, much of the information reported in the past five years is redundant. Even more problematic is the fact that the limited scope and robustness of the research calls into question the veracity of the data currently taken to represent the issue of Aboriginal youth gangs. The most recent publication on gangs in Canada by Mark Totten validates the lack of accurate statistics and calls for research to identify the scope of the problem (Totten, 2012).

\section{Social Construction of Aboriginal Youth Gangs}

An Aboriginal youth gang discourse premised upon questionable statistics and frequent speculation about high numbers serves to invoke fear. The fear, in turn, fuels recrimination through discrimination and racism levied against Aboriginal youth, and a tendency toward hypervigilance about Aboriginal youth behaviour that, in turn, leads to increased racial profiling and criminalization of Aboriginal youth (Mercredi, 2000; FSIN, 2003). Aboriginal youth experience an elevated and pervasive level of oppression from the general public and, more worrisome, from law enforcement, because they are targets of an extremely negative and charged perception (Mercredi, 2000: Grekul \& LaBoucane-Benson, 2008). Ironically, the negative discourse ultimately leads to increased gang involvement because, once incarcerated, Aboriginal youth are often forced to join gangs or affiliate with gangs in order to acquire protection and safety (CISS, 2005; Chettleburgh, 2007; FSIN, 2003; Goodwill, 2009; Mercredi, 2000; Totten, 2009a; 2009b). A former gang member in Grekul and LaBoucane-Benson's study (2008) reported that

The majority [of individuals recruited in prison] stay [with the gang] when they leave prison because sooner or later they will be back in prison and will need protection and support. (p. 72)

Indeed, a Saskatoon gang exit program coordinator describes the Saskatchewan correction system as "a recruiting ground" for Aboriginal gangs (Tu'Inukuafe 2011, personal communication) while a 2000 study described correctional centres as "training grounds" for gangs (Mercredi). Another study noted that some Aboriginal youth gangs in Canada "actually credit prison processes with their birth and creation" (Grekul \& Laboucan-Benson, 2007, p. 21). Institutional gang activity then interfaces with street level youth when they enter prison or once hardened 
individuals are released from institutions. According to Gordon (2000), these individuals will negatively influence youth gangs in terms of trafficking, violence, and access to weapons.

The evidence shows that Aboriginal youth gangs do exist and in some contexts are highly problematic. In western cities, it is rare that a week goes by without news reports of violent gang activity. However, gangs exist on a continuum from loosely knit groups of friends/relatives who may coalesce for protection and camaraderie and also engage in opportunistic petty crime together (Gordon, 2000), to hardened adult gang members in organized hierarchies with strong connections to some of the most notorious gangs in the world, including the Hell's Angels (Tu'Inukuafe 2011, personal communication; Chettleburgh, 2007; FSIN, 2003; Mercredi, 2000). Unfortunately, given the lack of research, the real scope of the issue is unknown. The public relies on sporadic media reports for their understanding of the issues, and those are often sensationalized because the reports are about extreme violence and crime. Often reports are about gang activity in the United States or in large Canadian centres like Vancouver, Toronto, and more recently, Montreal (Soulliere, 1998; Libin, 2010; Erickson, LaBoucane-Benson \& Grekul, 2007; Totten, 2008).

Interestingly, in many news reports, the ethnic make-up of gangs is not Aboriginal. However, it appears that some Aboriginal youth and especially those who come into contact with the justice system are assumed to be gang affiliated whether they actually are or not. These youth are faced with two powerful labels: "Aboriginal first and through stereotyping, gang members" (Grekul \& LaBoucane-Benson, 2008, p. 72). With these labels come a number of assumptions and behaviours that serve to further stigmatize and marginalize Aboriginal youth. Labels are powerful social constructions with potentially harmful consequences.

To be certain, gang crime and violence are a serious matter and a cause for concern. But the literature and, more importantly, the mass media, appear to inequitably and inappropriately focus on Aboriginal youth gangs as the most problematic. Media reporting, intentionally or not, seems to highlight Aboriginal youth gangs, regardless of whether they are actually the crux of the problem. For example, Jordana Huber (National Post, April 13, 2008), reporting on a rash of shootings in Toronto, Vancouver, and Surrey, BC, the epicenters for Black and Asian gangs, highlighted a Winnipeg "gang-style" shooting and mentioned a notorious Aboriginal gang, the Indian Posse. The fact that the article was actually about non-Aboriginal gangs was subsumed; readers were directed instead to see and retain the highlighted points about "youth gangs," "rash of shootings," and "Indian Posse," when a more salient point would have been the 14 gang-related homicides in Vancouver in the three-month period prior to the article, and several shootings in Surrey - none of which involved Aboriginal youth or adults! Focusing on and providing details about a single incident in Winnipeg worked to solidify a perception in the public mind that the "gang epidemic" is about Aboriginal people. An article by Kevin Libin of the National Post, in February 2008, reported on Aboriginal gangs:

If you go into North Winnipeg and you talk to the Aboriginal community and you ask them a question, "How many of the boys in your community, under 18, are gang-involved?" most often I get the answer, "All of them," says Michael Chettleburgh, author of Young Thugs: Inside the Dangerous World of Canadian Street Gangs. "If you went up to Edmonton or you go up to the Hobbema Reserve, you will see in those communities a level of poverty like I see down in some big cities in the United States. If you are a young Aboriginal male, growing up in that community where there is a persistent and an ambient sense of danger all the time, where there are ample drugs, where there are other gang-affiliated kids, when the economic prospects are 


\section{Aboriginal youth gangs in Canada: (de)constructing an epidemic}

marginal. ... "People will ask me, 'Why are kids joining gangs?' I say to them, 'Why aren't they joining gangs?”"

While it is true that the north end of Winnipeg has pockets of intense gang involvement, among other social pathologies, the danger is that the average reader may not discern that these are only pockets; they may instead apply that image to all Aboriginal people, perpetuating fear about Aboriginal gangs. The "mark of the plural" (Freire, 1972) is where the negative or harmful actions of the few are applied to the many. Aboriginal youth are being portrayed, on the whole, as frightening and violent gang predators on the prowl on Canadian streets. Using Hobbema as an example of youth gang violence in Canada is like using one small town as representative of the population in Canada. In the same way that a town population is not representative of the general population, the unique social, economic, and political context of Hobbema should not be applied to the rest of the country.

The written word can wield power and influence in the public mind and just as reporting can incite the public into an uproar over the "gang epidemic," so, too, can reporting quell fears and hysteria. As an example, one author describes Aboriginal youth gangs as an "epidemic of gang violence [with] young Aboriginal gang members ... killing each other and committing suicide at rates that exceed those of other groups in Canada" (Totten, 2009, abstract). However, in a report to the British Columbia Ministry of Public Safety and Solicitor General the previous year, he had this to say about youth gangs in general:

There are many myths perpetuated by the media and the general public which contribute to a social panic about youth gangs. In reality, the vast majority of B.C. youth are healthy, contributing members of society; less than 0.5 per cent belong to gangs. It is important to understand that most gangs in Canada are adult, not youth gangs. Further, the large majority of youth who are mistakenly classified as "gang members" are instead involved in anti-social behaviours which, although serious nonetheless, are not gang related. (Totten, 2008, p. 23)

The manner in which gangs are reported on in the media and in academic publications is important because such reports contribute to the overall perception of the problem as well as how Aboriginal youth are perceived in the public eye. It will also provide insights for solutions.

We need to critically assess how it is that the current construction of youth gang activity has come to dominate at this point in time ... the role it plays in constructing the problem will certainly have to be part of constructing a solution. (Grekul \& LaBoucane-Benson, 2007, p. 23)

One solution is to examine how youth become labeled as gang members. Totten's comment about mistaken classification is highly salient to Aboriginal youth gangs: the point where Aboriginal youth interface with the justice system is often the juncture where they become defined and labeled as gang members.

\section{Gang Definitions, Types, and Labeling}

A good selection of literature addresses the problem of how gangs are defined, and RichterWhite (RCMP, 2003 citing Venkatesh, 1996) observed:

Youth congregating in gangs seems to be one of the most misunderstood and negatively interpreted phenomena of youth. Membership in a youth gang does not necessarily guarantee a negative short or long-term outcome for a youth and/or society, or the direct passage into organized criminal groups as many media sources have purported. Instead, gangs often 
First Peoples Child \& Family Review, Volume 7, Number 1, 2012

provide an immediate wage and/or a direct sense of community and identity for youth whose economic and social opportunities are limited. (p. 17)

According to Gordon (2000), analysts and policy makers should be thinking of gangs along a continuum, ranging from groups of friends who spend time together and occasionally get into trouble, to more serious organized criminal groups or gangs (p. 51). Aboriginal youth gang members themselves report that gang members are not perceived as vastly different from other members of Aboriginal society (Lafontaine et al., 2009), and many Aboriginal youth and young adults in prisons or correctional centres resist and resent being automatically labeled as gang members when they don't see themselves that way (FSIN, 2003; Mercredi, 2000; Grekul \& LaBoucane-Benson, 2008).

Several typologies have emerged as researchers and academics grapple with the issue of labeling. These are summarized in Table 3 (p. 20). Mellor and colleagues (2005) conducted a review of youth gang programs and services, and in the course of that review identified five types of gang involvement that were primarily differentiated based on criminal activity (p. 8). Perhaps even more valuable in relation to the often loosely-knit nature of Aboriginal youth gangs is the second typology adapted from Gordon's (2000) article on Vancouver gangs. This typology is important for its application to a street-level analysis of gangs, where the categories are less rigidly defined but inclusive and revealing of the scope of labeling that occurs. This is very much aligned with Tu'Inukuafe's comments that Aboriginal youth, especially teens, have a very fluid membership approach that is often opportunistic and is motivated through family/friend relationships (2011, personal communication).

Mellor et al.s (2005) typology of gangs identifies five types of involvement determined by the amount of criminal activity that a group displays, recruitment strategies, and the structures that are in place to support the gang (p. 8).

Mellor et al's (2005) typology has been widely referenced and applied. Its utility is based on the continuum of criminal involvement, which, in much of the literature that is sponsored by law enforcement, criminal intelligence, or public safety, is what gang concerns are centred on. Gordon's typology is primarily based on the last two categories, with the first two added based on Gordon's descriptions of how youth are labeled by others. The "Street Gangs" category is all-encompassing. The "Wanna-be Gangs" category is important because it encompasses the category of Aboriginal youth who may not actually be gang members but gather together in large groups for belonging, safety, a desire for respect and reputation, and for fun or criminal behaviour. Social exclusion and limited access to opportunities in urban centres may result in more Aboriginal youth clustering together (Dukes et al., 1997).

For Aboriginal Youth who utilize the wanna-be strategy, there is the risk they will be treated like gang members by real gang members as well as the police and the general public. A 13-year old boy was shot and killed because he responded "straight up" when asked if he was a member of the Indian Posse by a youth in a passing vehicle (Grekul \& LaBoucane-Benson, 2008). Another youth reported his friend intentionally wearing colours of three different gangs: "And I happen to know that that kid is carrying 3 rags. Why? Because he doesn't want to get his ass kicked, and he is not even gang affiliated at all" (Henry, 2009, p. 58). 


\section{Aboriginal youth gangs in Canada: (de)constructing an epidemic}

Table 3: Gang Typologies

\begin{tabular}{|c|c|}
\hline \multicolumn{2}{|c|}{ (Mellor et al. 2005, p. 8) } \\
\hline Type A: & $\begin{array}{l}\text { A group of friends who tend to be interest-based (e.g., sports teams, skateboarders) and } \\
\text { usually do not engage in criminal activity. They pose no threat to the community and } \\
\text { therefore should be encouraged. }\end{array}$ \\
\hline Type B: & $\begin{array}{l}\text { Spontaneous criminal activity gangs are social in nature and gather their power and } \\
\text { status through their numbers. Criminal activity is situationally motivated and can be } \\
\text { categorized as gratuitous violence and bullying due to a lack of supervision. These } \\
\text { youth usually do not move to the next level because they have other options, either } \\
\text { economically or socially outside the gang. }\end{array}$ \\
\hline Type C: & $\begin{array}{l}\text { Purposive gangs come together for a specific purpose. Whether stealing cars, engaging } \\
\text { in vigilante-type violence, or spontaneous mob activity, these gangs can emerge from } \\
\text { larger gangs and usually disband once the purpose has been accomplished. }\end{array}$ \\
\hline Type D: & $\begin{array}{l}\text { Youth street gangs are highly visible hardcore groups that come together primarily for } \\
\text { profit-driven criminal activity. These street gangs identify themselves as such through } \\
\text { the adoption of a gang name, common brands, styles, clothing, colours, jewellery, and } \\
\text { tattoos. These gangs do not seem to be part of a larger criminal organization and often } \\
\text { have a territory or turf that they claim and defend as their own. }\end{array}$ \\
\hline Type E: & $\begin{array}{l}\text { Structured criminal organizations are networks that tend to be led by criminally } \\
\text { experienced adults for the purpose of economic or financial gain. The criminal activity } \\
\text { of these types of gangs tends to be severe in nature and premeditated. Youth are often } \\
\text { used for specific purposes to further the gang's activities. Examples of these types } \\
\text { of gangs in Saskatchewan include the Indian Posse, Saskatchewan Warriors, Native } \\
\text { Syndicate, and Hells Angels (Mellor et al., 2005, p. vi). }\end{array}$ \\
\hline \multicolumn{2}{|c|}{ (Adapted from Gordon, 2000) } \\
\hline $\begin{array}{l}\text { Media } \\
\text { Constructed Gang }\end{array}$ & $\begin{array}{l}\text { Small groups of offenders referred to as gangs when they do not see themselves } \\
\text { that way; media use of inaccurate terms that distort and amplify gang problem. Media } \\
\text { imposes a name; e.g. "Back Alley Boys" was given to teen bullies who were robbing their } \\
\text { peers in back alleys. }\end{array}$ \\
\hline $\begin{array}{l}\text { Police } \\
\text { Constructed Gang }\end{array}$ & $\begin{array}{l}\text { Similar to media constructed gangs. Police apply a name to a collectivity that is } \\
\text { engaged in criminal activity together or engaged in the same criminal activity. For } \\
\text { example, the " } 626 \text { gang" were a group of youth and adults who engaged in a rash of } \\
\text { stealing Mazda } 626 \text { vehicles. In Saskatoon, the "Oldsmobile gang" label was applied to } \\
\text { youth and adults who opportunistically stole Oldsmobile vehicles. }\end{array}$ \\
\hline Street Gangs & $\begin{array}{l}\text { Groups of young people, mainly adults, who come together and form a semi- } \\
\text { structured organization to profit from criminal behaviour and acquire territory. They } \\
\text { self-identify as a gang and have identifying marks, colours. They openly identify with } \\
\text { some visibility because they want to be seen as gang members by others. }\end{array}$ \\
\hline Wanna-be Gangs & $\begin{array}{l}\text { Clusters of young people who band together in loosely structured groups to engage } \\
\text { in spontaneous social or criminal activity, including peer violence. Highly visible and } \\
\text { display gang involvement to be seen by others as gang members. May use clothing, } \\
\text { colours, or other identifying marks. }\end{array}$ \\
\hline
\end{tabular}


First Peoples Child \& Family Review, Volume 7, Number 1, 2012

Similarly, Gordon's category of "Media Constructed" gangs explains the labeling by media and police that misrepresents all youth who gather together and break the law as gang members. According to Grekul \& LaBoucane-Benson (2008), the label of "gang" is a highly judgemental one and an "overtly negative term applied indiscriminately by adults to groups of adolescents ranging from friends hanging out who occasionally get in trouble, to more serious organized criminal gangs" (citing Mathews, 2005, p. 204). Labeling Aboriginal youth can be especially problematic because of their existing marginalization.

Labeling stereotypes can lump particular individuals into the same category, and this can have a marginalizing effect on youth, which further distances them from the community. Because marginalization inhibits social mobility, mislabeled youth may actually become more likely to engage in a gang lifestyle (Henry, 2009, p. 59).

Labeling is risky because it may also be inaccurate. Phil Fontaine, the former elected leader of the Assembly of First Nations, was erroneously labeled by police as a gang member and had to take legal action to have his name removed from the gang list (Mercredi, 2000). Criteria for consistent application across the country, and even within provinces, are absent in the literature, and the omission of relevant definitions and criteria for identifying Aboriginal youth gang numbers and membership point to a severe limitation in the research and the literature. It challenges the veracity of the conclusions. "National studies can be misleading if communities do not share an understanding of what defines youth gangs, or the criteria used to define a gang" (Henry, 2009, p. 30).

\section{The Connection between Aboriginal Youth, Gangs, and Prison}

Aboriginal youth and the prison system are intricately connected, much more so than any other ethnic group. Aboriginal gangs are a relatively new phenomenon; the widespread belief is that Aboriginal gangs established a presence in Saskatchewan through the federal and provincial correctional centres in the mid- to late 1990s. Their numbers seemed to gain momentum following a 1997 riot at Stoney Mountain Penitentiary (CISS, 2005). After the riot, Manitoba gang leaders were moved to secure custody in Saskatchewan institutions where they began recruiting new members: "This redistribution of gang members into other prisons ironically facilitated widespread recruiting, therefore expanding their territory and control” (Henry 2009, p. 16). In prison, Aboriginal youth who are newly sentenced or first-time offenders are particularly likely to join a gang for protection purposes, and released prisoners continue recruitment and gang activity upon release (Mercredi, 2000).

Although the relationship between gangs and prisons is not completely clear, it is certain that a connection exists (Grekul \& LaBoucane-Benson, 2007). In some instances, incarcerated Aboriginal youth/adults join gangs in prisons and find respect and recognition they didn't have before. A corrections employee observed that "with Redd Alert - lots of them found recognition in gangs. They hadn't had that before - they were abused, put down all their lives. They got in the gang and had a name. 'I'm somebody.' They got recognition and a sense of belonging" (Grekul \& LaBoucane-Benson, 2008, p. 42).

\section{Healthy Aboriginal Youth and Protective Factors}

Despite the tremendous obstacles facing Aboriginal youth, an area of literature that has recently received increasing attention addresses resiliency. There is a significant gap in literature 


\section{Aboriginal youth gangs in Canada: (de)constructing an epidemic}

on successes in Aboriginal communities, but some research has highlighted community protective and insulating factors as having significant implications for youth wellness. One study that addressed the mental health of Aboriginal people observed that incorporating cultural concepts, including interconnectedness and spirituality, into counselling tapped into the need for reconnection. Likewise, incorporating ceremony and principles of empowerment, cleansing, balance, discipline, and belonging into healing practices facilitated effective and relevant Indigenous healing processes for participants (McCormick, 2000).

At the community and structural levels of intervention, Chandler and Lalonde (1998) identified a cultural continuity model that enhanced community wellness as well as individual agency and efficacy in community members. The authors confirm earlier research by Minore et al (1991; cited in Bennett et al., 2005) that community control of health, education, police and fire services, cultural activities, self-government, and land claims all combined to reduce suicide levels (cited in Goodwill, 2009).

When communities succeed in promoting their cultural heritage and in securing control of their own collective future - in claiming ownership over their past and future - the positive effects reverberate across many measures of youth health and well-being. Suicide rates fall, fewer children are taken into care, school completion rates rise, and rates of intentional and unintentional injury decrease (Lalonde, 2005, p. 23).

We can extrapolate that efforts to augment personal and community efficacy and agency lead to positive mental and social health outcomes. Lalonde's work informs us that resilience in Aboriginal youth is intricately connected with culture and control in Aboriginal communities, and validates the finding that culturally based intervention programs are the ones proving to be most effective with Aboriginal gang members. One example is the Str8 Up program out of Saskatoon.

The Str8 Up program was started for individuals wanting to escape gang life, and it stands among the most comprehensive gang exit programs currently operating. Based on an American program, it was adapted for a Canadian/Saskatchewan context and may provide a model for development. It is unique in that participants self-identify and self-select. It is not supported by core funding; its 50 members raise all operating funds through speaking engagements, and program information is disseminated by word of mouth. There is no age limit, but participants are generally over 18 .

The program has three goals for participants: to be responsible citizens, to be faithful partners, and to be loving parents. In addition, there are five conditions each participant must be willing to adhere to:

- Drop their gang colours

- Deal with their addiction

- Be honest (drop "attitude" and manipulative ways)

- Be humble

- Be willing to give the program a chance by accepting support and committing to partake for 4 years (John Howard Society).

Program activities include visiting peers in the correctional facility and holding meetings there; and presenting in schools, reserves, addiction centres, and any organization that expresses a need or interest. The group meets once a week and participants learn about healthy lifestyles 
and positively contributing to and partaking in community. They enjoy recreational activities and have barbecues. The program offers strong leadership modeling as well as social support with housing, employment, and general community errands (Tu'Inukuafe 2011, personal communication).

Until evaluation research can confirm what we suspect, it appears that the success of best practices programs is rooted in their holistic approach, based on an Indigenous/holistic framework and the pragmatic approach to changing behaviours. There is a lot of research to be done in the area of Aboriginal youth gangs and it should be conducted by Aboriginal researchers with life, cultural, and worldview experiences similar to Aboriginal youth gang members. Goodwill (2009) notes that the existing chasm in the literature needs to be filled by community member perspectives. "It is important in understanding Aboriginal gang issues from community members' perspectives because they have their fingers on the pulse of the problem as they live with the effects of gangs in their communities on a daily basis" (p. 34-35).

\section{Conclusion}

Many of the factors that lead to Aboriginal youth gang involvement are linked to the colonial history of Canada and include intergenerational trauma, family and community breakdown, and Aboriginal child welfare involvement. Gang involvement is invariably connected to alternative care, which is implicated as a source for problematic intrapersonal and mental health issues, including attachment and bonding, criminality, homelessness, suicide, and general social exclusion. Compounding the structural issues, a critical analysis informs us that contemporary issues of discrimination and oppression also play out in the social construction of Aboriginal youth and youth gangs as problematic. What the research and the analysis clearly reveal is that Aboriginal youth gang involvement is the outcome of a complex system of social distress, and the juxtaposition of multiple risk factors facing Aboriginal people in Canada.

This article synthesized the available gang statistics in order to observe the limitations, contradictions, and gaps in the data, which, by their omission, provide sound direction for future research. In summary, although Aboriginal youth gangs exist and in some contexts are highly problematic, the data lacks robustness and is statistically unreliable because most of the statistics reported are based on one report that provided hypothetical estimations for gang membership numbers in 2002. Additional data from police organizational reports is often not referenced to an original source, so its veracity cannot be verified without much more detailed and time-intensive research. The limitations of the statistics exacerbate concerns around the definition of gangs in Canada, especially Aboriginal youth gangs. At the point where gang members can be tallied - the justice system - any existing definitional guidelines may or may not accurately reflect gang membership; definitions that describe gangs as "individuals who commit crimes together" are extremely limited and untrustworthy. Youth gang statistics need more robust quantitative research that can accurately inform researchers, theorists, and the public, and thereby prevent inaccurate information from being drawn upon by media and perpetuated by academics and researchers.

Issues surrounding definitions and typologies reveal that attention must be paid to the social construction of gangs in Canada, and how that discourse fuels social and legal relations among Aboriginal youth, and by implication their families and communities, the justice system, and society in general. Analysis of the youth gang reporting in both academic literature and the news media reveals that the discourse is often highly charged; this only serves to further marginalize 


\section{Aboriginal youth gangs in Canada: (de)constructing an epidemic}

Aboriginal youth, compounding their social distress and enhancing the systemic barriers that lead to gang involvement in the first place.

Prevention and intervention programs that focus on Aboriginal youth are limited in number, but several promising programs exist that are premised upon cultural appropriateness and relevance, and these appear to be relatively successful in helping youth to exit gangs. Ultimately, funding for programs and support for research into best practices with Aboriginal youth gangs will go a long way toward providing a more complete picture of the scope of the gang problem and determining which interventions are most effective.

\section{References}

Adelson, N. (2005). The Embodiment of Inequity: Health Disparities in Aboriginal Canada. In The Canadian Journal of Public Health, 96 (Suppl.2), S45-S61.

Armitage, A. (1995). Comparing the Policy of Aboriginal Assimilation: Australia, Canada and New Zealand. Vancouver, BC: The University of British Columbia Press.

Bania, M. (2009). Gang Violence Among Youth and Young Adults: (Dis)Affiliation and the Potential for Prevention. In IPC Review, 3, 89-116. http://www.sciencessociales.uottawa.ca/ipc/eng/documents/IPCR3Bania.pdf

Bennett, M., C. Blackstock, \& R. De la Ronde. (2005). A Literature Review and Annotated Bibliography on Aspects of Aboriginal Child Welfare in Canada. 2nd ed. Ottawa, ON: First Nations Child and Family Caring Society. http:// www.fncfcs.com/docs/AboriginalCWLitReview2ndEd.pdf

Bowlby J. (1973). Attachment and Loss. Volume II: Separation, Anxiety and Anger. London: Hogarth Press.

Brand, A. E. \& P. M. Brinich. (1999). Behavior Problems and Mental Health Contacts in Adopted, Foster and NonAdopted Children. In Journal of Child Psychology and Psychiatry, 40(8), 1221-1229.

Brandon, M., M. Ower, \& J. Black. (1999). Learning How to Make Children Safe: An Analysis for the Welsh Office of Serious Child Abuse Cases in Wales. Norwich: University of East Anglia.

Brizinski, P. (1993). Knots in a String: An Introduction to Native Studies in Canada. Saskatoon, SK: University of Saskatchewan Extension Press.

Canadian Institutes of Health Research (CIHR). (2007). CIHR Guideline for Health Research Involving Aboriginal People. Ottawa, ON: Canadian Institutes of Health Research.

Chandler, M. J. \& C. Lalonde. (1998). Cultural Continuity as a Hedge Against Suicide in Canada's First Nations. In Transcultural Psychiatry, 35, 191-219.

Chettleburgh, M. C. (2002). Results of the Canadian Police Survey on Youth Gangs. Toronto, ON: Astwood Strategy Cooperation.

Chettleburgh, M. (2007). Young Thugs: Inside the Dangerous World of Canadian Street Gangs. Toronto, ON: Harper Collins.

Chrisjohn, R. \& S. Young. (2006). The Circle Game: Shadows and Substance in the Indian Residential School Experience in Canada. Penticton, BC: Theytus Books.

Cradock, G. (2007). The Politics of Kith and Kin: Observations on the British Columbia Government's Reaction to the Death of Sherri Charley. In First Peoples Child and Family Review, Vol. 3(1), 15-33.

Criminal Intelligence Service Saskatchewan. (2005, 2010). Intelligence Trends: Aboriginal-Based Gangs in Saskatchewan. Regina, SK: CISS. 


\section{First Peoples Child \& Family Review, Volume 7, Number 1, 2012}

Dukes, R. L., R. O. Martinez, \& J. A. Stein. (1997). Precursors and Consequences of Membership in Youth Gangs. In Youth and Society, 29(2), 139-165.

Duran, E. \& B. Duran. (1995). Native American Postcolonial Psychology. Albany, NY: State University of New York Press.

Duran, B, E. Duran, \& M. Yellowhorse Brave Heart. (1998). Native Americans and Trauma of History. In Studying Native America: Problems and Prospects, R. Thornton, (Ed.). Madison: University of Wisconsin Press. 60-76.

Erickson, K., P. LaBoucane-Benson, \& J. Grekul. (2007). The Community Solution to Gang Violence: A Collaborative Community Process and Evaluation Framework. In Aboriginal Peoples Collection. Ottawa: Aboriginal Corrections Policy Unit, Public Safety Canada.

Federation of Saskatchewan Indian Nations. (2003). Alter-natives to Non-Violence Report: Aboriginal Youth Gangs Exploration: A Community Development Report. Saskatoon, SK: Federation of Saskatchewan Indian Nations.

Fournier, S. \& E. Crey. (1997). Stolen from Our Embrace: The Abduction of First Nations Children and the Restoration of Aboriginal Communities. Vancouver, BC: Douglas \& MacIntyre.

Freire, P. (1972). Pedagogy of the Oppressed. New York: Herder \& Herder.

Frideres, J. S. (1988). Native Peoples in Canada: Contemporary Conflicts. 4th ed. Scarborough: Prentice Hall.

Gilchrist, L. (1995). Kapitipis e-pimohteyahk: Aboriginal Street Youth in Vancouver, Winnipeg and Montreal. PhD diss., University of British Columbia.

Golding, K. (2003). Helping Foster Carers, Helping Children: Using Attachment Theory to Guide Practice. In Adoption \& Fostering Journal, 27(2), 64-73.

Goodwill, A. (2009). In and Out of Aboriginal Gang Life: Perspectives of Aboriginal Ex-Gang Members. University of British Columbia. Doctoral Dissertation. June 2009.

Gordon, R. (2000). Criminal Business Organizations, Street Gangs and "Wanna-Be" Groups: A Vancouver Perspective. In Canadian Journal of Criminology, 42(1), 39-60.

Gough, P., N. Trocmé, I. Brown, D. Knoke, \& C. Blackstock. (2005). Pathways to Overrepresentation of Aboriginal Children in Care. (CECW Information Sheet \#23E). Toronto, ON: University of Toronto.

Grekul, J. \& P. LaBoucane-Benson. (2007). An Investigation into the Formation and Recruitment Processes of Aboriginal Gangs in Canada. In Aboriginal Peoples Collection. Ottawa: Aboriginal Corrections Policy Unit, Public Safety Canada.

Grekul, J. \& P. LaBoucane-Benson. (2008). Aboriginal Gangs and Their (Dis)placement: Contextualizing Recruitment, Membership and Status. In Canadian Journal of Criminology and Criminal Justice, 50(1), 59-82.

Henry, R. (2009). Just Another Thug: The Implications of Defining Youth Gangs in a Prairie City. MA thesis, University of Saskatchewan.

Huber, J. (2008). Rash of Shootings Linked to Youth Flocking to Gangs. National Post. Available at http://www. nationalpost.com/news/Rash+shootings+linked+youth+flocking+gangs/443400/story.html

John Howard Society. Saskatoon. Str8 Up program description. Available at: http://www.sk.johnhoward.ca/services/ saskatoon/\#str8

Johnston, Patrick. (1983). Native Children and the Child Welfare System. Canadian Council on Social Development. Toronto: Lorimer.

Kirmeyer, L., C. Tait, \& G. Brass. (2000). The Mental Health of Aboriginal Peoples: Transformations of Identity and Community. In Canadian Journal of Psychiatry, 45, 607-616.

Kellner, D. (1989). Critical Theory, Marxism, and Modernity. Baltimore: Johns Hopkins University Press.

(c) Raven Sinclair and Jana Grekul 


\section{Aboriginal youth gangs in Canada: (de)constructing an epidemic}

Krinsky, M.A. (2010). Disrupting the Pathway from Foster Care to the Justice System - A Former Prosecutor's Perspectives on Reform. In Family Court Review, 48(2), 322-327.

Lafontaine, T., S. Acoose, \& B. Schissel. (2009). Healing Connections: Rising About the Gang. In Journal of Gang Research, 16(2), 27-55.

Leonard, S. (1990). Critical Theory in Political Practice. Princeton, NJ: Princeton University Press.

Levitt, K. L. \& B. Wharf. (1985). The Challenge of Child Welfare. Vancouver, BC: University of British Columbia Press.

Libin, K. (2010). Real Warriors Hold Jobs. National Post. February 20, 2008.

Matthews, F. (2005). Youth Gangs. In Winterdyk, J. (Ed.). Issues and Perspectives on Youth Offenders in Canada (3rd ed.). Toronto: Thomson Nelson.

Maurice, J. (2003). De-Spiriting Aboriginal Children: Western Constructions and Destructions of Aboriginal Children in the Child Welfare System During the 1960s and 70s. PhD Dissertation. University of Toronto.

McCormick, R. (2000). Aboriginal traditions in the treatment of substance abuse: Let only the good spirits guide you. Canadian Journal of Counselling, 34(1), 25-32.

Mckenzie, B. \& P. Hudson. (1985). Native Children, Child Welfare and Colonization of Native People. In The Challenge of Child Welfare, B. Wharf \& K. Levitt (Eds.), 125-141. Vancouver, BC: University of British Columbia Press.

Mellor, B., L. MacRae, M. Pauls, \& J.P. Hornick. (2005). Youth Gangs in Canada: A Preliminary Review of Programs and Services. Ottawa: Public Safety and Emergency Preparedness Canada.

Mercredi, O. (2000). Aboriginal Gangs: A Report to the Correctional Service of Canada on Aboriginal Youth Gang Members in the Federal Corrections System. Ottawa: Aboriginal Issues Branch, Correctional Service of Canada.

Miller, J. (1996). Shingwauk's Vision: A History of the Native Residential Schools. Toronto: University of Toronto Press.

Milloy, J. (1999). A National Crime: The Canadian Government and the Residential School System, 1879 to 1986. Winnipeg: University of Manitoba Press.

Minore, B., Boone, M., Katt, M., \& Kinch, P. (1991). Looking In, Looking Out: Coping with Adolescent Suicide in the Cree and Ojibway Communities of Northern Ontario. The Canadian Journal of Native Studies, 11, 1-24.

Mullaly, B. (1997). Structural Social Work: Ideology, Theory, and Practice, 2nd ed. Toronto: Oxford University Press.

Neckoway, R., K. Brownlee, L. W. Jourdain, \& L. Miller. (2003). Rethinking the Role of Attachment Theory in Child Welfare Practice with Aboriginal People. In Canadian Social Work Review, 20(1), 105-119.

Neu, D. \& R. Therrien. (2003). Accounting for Genocide: Canada's Bureaucratic Assault on Aboriginal Peoples. Halifax, NS: Fernwood.

Preston, J. P., S. Carr-Stewart, \& C. Northwest. (2009). Aboriginal Youth Gangs: Preventative Approaches. In First Peoples Child and Family Review, 4(2), 152-160.

Proulx, J. \& Perreault, S. (1996). An Evaluation of the Ma Mawi Chi Itata Centre's Family Violence Program, Stony Mountain Project. Winnipeg: Ma Mawi Wi Chi Itata Centre.

Public Safety Canada. (2010). Eastside Aboriginal Space for Youth (EASY). Vancouver, BC: Public Safety Canada.

Public Safety Canada. (2007). Youth Gangs in Canada: What Do You Know? Ottawa: National Crime Prevention Centre, Public Safety Canada. http://www.publicsafety.gc.ca/prg/cp/bldngevd/2007-yg-1-eng.aspx.

RCMP Gazette. (2008). Panel Discussion. Vol. 70(2). Archived at http://www.rcmp-grc.gc.ca/gazette/vol70n2/paneleng.htm

Reading, J. (2010). The Crisis of Chronic Disease Among Aboriginal Peoples: A Challenge for Public Health, Population Health, and Social Policy. Victoria, BC: Centre for Aboriginal Health Research. 


\section{First Peoples Child \& Family Review, Volume 7, Number 1, 2012}

Richter-White, H. (2003). The Direct and Indirect Impacts of Organized Crime on Youth, as Offenders and Victims. Ottawa: RCMP. March 2003.

Royal Commission on Aboriginal Peoples. (1996). People to People, Nation to Nation: Highlights from the Report of the Royal Commission on Aboriginal Peoples. Ottawa: The Commission. http://www.inac.gc.ca/rcap/report/index. html

Saskatchewan Child Welfare Review Panel Report. (2010). For the Good of Our Children and Youth: A New Vision, a New Direction. Available at: http://saskchildwelfarereview.ca/CWR-panel-report.pdf

Saskatchewan Children's Advocate. (2005). A Summary of Child Death Reviews 2000 and 2001. Available at: http:// www.saskcao.ca/sites/default/files//pdfs/reports/caocdrsummaryreportIII.pdf

Sheremeta, D. (1999, March 1). Big Bear meets Al Capone: Winnipeg's feared Native gangs bring their volatile mix of organized crime and Indian radicalism to wildrose country. Alberta Report (Online Newsmagazine). Available at http://albertareport.com/volume26/990301/story1.html

Sinclair, J. M., D. Phillips, \& N. Bala. (1991). Aboriginal Child Welfare in Canada. In Canadian Child Welfare Law: Children, Families and the State, N. Bala, J.P. Hornick, \& R. Vogi (Eds.), 199-245. Toronto: Thompson Educational Publishing Inc.

Sinclair, R. (2007a). Identity Lost and Found: Lessons from the Sixties Scoop. In First Peoples Child and Family Review, $3(1), 65-82$.

Sinclair, R. (2007b). All My Relations - Native Transracial Adoption: A critical case study of cultural identity. University of Calgary: Doctoral Dissertation.

Sinclair, R. (2010). Wicihitowin: Aboriginal Social Work in Canada. Winnipeg: Fernwood Press.

Soullière, N. (1998). Youth and Gangs: Various Views, Random and Varied Strategies. Regina: Research Centre, Canadian Police College.

Stevenato and Associates, J. Budgell. (1998). Repatriation of Aboriginal Families. Toronto: Native Child \& Family Services. Aboriginal Healing and Wellness Strategy.

Stolen Generations. (2003). The Book of Voices: Voices of Aboriginal Adoptees and Foster Children. Winnipeg: Aboriginal Healing Foundation.

Swidrovich, C. (2004). Positive experiences of First Nations Children in non-Aboriginal foster or adoptive care: Deconstructing the "Sixties Scoop". Master's thesis. University of Saskatchewan. Saskatoon.

Timpson, J. (1995). Four Decades of Literature on Aboriginal Canadian Child Welfare: Changing Themes. In Child Welfare, 74(3), 525-546.

Totten, M. (2008). Promising Practices for Addressing Youth Involvement in Gangs. Vancouver, BC: British Columbia Ministry of Public Safety and Solicitor General, Victim Services and Crime Prevention Division.

Totten, M. (2009a). Aboriginal Youth and Violent Gang Involvement in Canada: Quality Prevention Strategies. In IPC Review, 3, 135-156.

Totten, M. (2009b). Preventing Aboriginal Youth Gang Involvement in Canada: A Gendered Approach. Prepared for Aboriginal Policy Research Conference, Ottawa. March 9-12, 2009.

Totten, M. (2012). Nasty, Brutish, and Short: The lives of gang members in Canada. Toronto: Lorimer Press.

Trevethan, S., J. Moore, S. Auger, M. MacDonald, \& J. Sinclair. (2002). Childhood Experiences Affect Aboriginal Offenders. In Forum on Corrections Research, 14(3), 7-9. http://www.csc-scc.gc.ca/text/pblct/forum/e143/ e143ind-eng.shtml.

(c) Raven Sinclair and Jana Grekul 


\section{Aboriginal youth gangs in Canada: (de)constructing an epidemic}

Trocme N., B. MacLaurin, B. Fallon, J. Daciuk, D. Billingsley, M. Tourigny, M. Mayer, J. Wright, K. Barter, G. Burford, J. Hornick, R. Sullivan, \& B. McKenzie. (2001). Canadian Incidence Study of Reported Child Abuse and Neglect: Final Report. Ottawa, Ontario: Minister of Published Works and sc.gc.ca/pphbdgspsp/publicat/cisfr-ecirf/pdf/cise.pdf.

Venkatesh, S.A. (1996). The Gang and the Community. In Gangs in America, C.R. Huff (Ed.). Thousand Oaks, CA: Sage Publications, Inc.

Waldram, J. B. (1997). The Way of the Pipe: Aboriginal Spirituality and Symbolic Healing in Canadian Prisons. Peterborough: Broadview Press.

Weinberg, M. (2008). Structural Social Work: A moral compass for ethics in practice. Critical Social Work, Vol. 9(1).

Wharf, B. (Ed.). (1993). Rethinking child welfare in Canada. Toronto: McClelland and Stewart. 